\title{
The influence of different salinity conditions on egg buoyancy and development and yolk sac larval survival and morphometric traits of Baltic Sea sprat (Sprattus sprattus balticus Schneider)
}

\author{
CHRISTOPH PETEREIT ${ }^{1}$, HANS-HARALD HINRICHSEN ${ }^{1}$, RÜDIGER VOSS ${ }^{2}$, \\ GERD KRAUS $^{3}$, MARKO FREESE ${ }^{1}$ and CATRIONA CLEMMESEN ${ }^{1}$ \\ ${ }^{1}$ Leibniz Institute of Marine Sciences (IFM-GEOMAR), Duesternbrooker Weg 20, 24105 Kiel, Germany. \\ E-mail: cpetereit@ifm-geomar.de \\ ${ }^{2}$ Sustainable Fisheries, Department of Economics, University of Kiel, Wilhelm-Seelig Platz 1, 24118 Kiel, Germany. \\ ${ }^{3}$ Institute of Sea Fisheries, Johann Heinrich von Thünen-Institut, Federal Research Institute for Rural Areas, \\ Forestry and Fisheries, Palmaille 9, 22767 Hamburg, Germany.
}

\begin{abstract}
SUMARY: The small pelagic sprat (Sprattus sprattus) is a key ecologic player in the Baltic Sea. However, there is longterm variability in recruitment which is thought to be influenced by fluctuations in abiotic and biotic conditions experienced during the early life stages. This study concentrates on the influence of different ambient salinities on sprat egg development, egg buoyancy and survival as well as early yolk sac larval morphometric traits. Egg buoyancy significantly decreased with increasing salinity experienced during fertilization and/or incubation experiments. Field egg buoyancy measurements in 2007 and 2008 exhibited annual and seasonal differences in specific gravity, potentially associated with changes in adult sprat vertical distribution. Neither egg development time nor the duration of the yolk sac phase differed among salinity treatments. At eye pigmentation, larval standard length exhibited high variance among individuals but did not differ among treatments. The largest ecological impact of salinity experienced during spawning was the modification the buoyancy of eggs and yolk sac larvae, which determines their vertical habitat in the Baltic Sea. There are strong thermo- and oxyclines in the Baltic Sea, and thus salinity can indirectly impact the survival of these early life stages by modifying the ambient temperatures and oxygen conditions experienced.
\end{abstract}

Keywords: clupeids, vertical distribution, specific gravity, drift, recruitment, spawning stock, adult fish.

RESUMEN: INFLUENCIA DE DIFERENTES CONDICIONES DE SALINIDAD EN LA FLOTABILIDAD DE LOS HUEVOS, DESARROLLO Y SUPERVIVENCIA DE LARVAS LECITOTRÓFICAS, Y RASGOS MORFOMÉTRICOS DEL ESPADÍN DEL MAR BÁLTICO (SPRATTUS SPRATTUS BALTICUS SCHNEIDER). - El espadín (Sprattus sprattus) es un pequeño pelágico que juega un papel ecológico clave en el mar Báltico. No obstante, se considera que la variabilidad a largo plazo en el reclutamiento está influenciada por condiciones bióticas y abióticas experimentadas durante los primeros estadios de desarrollo. Este estudio se concentra en la influencia de diferentes salinidades ambiente sobre el desarrollo de los huevos de espadín, su flotabilidad y supervivencia, así como sobre los rasgos morfométricos de las larvas lecitotróficas. La flotabilidad de los huevos disminuye significativamente con los incrementos de salinidad experimentados durante los experimentos de fertilización y/o incubación. Las medidas de flotabilidad en el medio mostraron diferencias en la gravedad específica de carácter anual y estacionales en 2007 y 2008 , potencialmente asociadas a cambios en la distribución vertical de los adultos de espadín. Ni el tiempo de desarrollo de los huevos ni la duración de la fase lecitotrófica difirió entre los tratamientos de salinidad. En el estadio de pigmentación de los ojos la longitud estándar de las larvas mostró importante variabilidad entre individuos, pero no entre tratamientos. El mayor impacto ecológico debido a la salinidad experimentada durante la puesta fue la modificación de la flotabilidad de los huevos y larvas lecitotróficas, lo que determina su hábitat vertical en el mar Báltico. En este mar se dan importantes termo- y oxiclinas y, por tanto, la salinidad puede impactar indirectamente en la supervivencia de estos primeros estadios de desarrollo a través de la modificación de las condiciones ambientales de temperatura y oxígeno en las que se desarrollen.

Palabras clave: clupeidos, distribución vertical, gravedad específica, deriva, reclutamiento, stock de puesta, peces adultos. 


\section{INTRODUCTION}

The population dynamics of sprat (Sprattus sprattus) are driven by large variability in recruitment caused by fluctuations in abiotic (Grauman and Yula, 1989; Köster et al., 2003) and biotic (e.g. Köster and Möllmann, 2000) conditions experienced by early life stages (ELS). Sprat in the Baltic Sea inhabits waters with the lowest salinities and temperatures experienced by this species (Muus and Nielsen, 1999) and displays adaptations to the environment (Kändler, 1941; Parmanne et $a l .$, 1994). The highly stratified, deep basins in the central Baltic Sea are known to be the major spawning grounds of Baltic sprat. Abiotic conditions vary spatially and seasonally, which leads to changing conditions for survival and development of ELS. Baltic sprat can have a prolonged spawning season lasting from March to August (Aro, 1989) and display diel vertical migration through thermo- and haloclines (Stepputtis, 2006). Due to these factors, different batches of eggs probably experience markedly different abiotic conditions. Although previous studies have quantified the influence of temperature on the survival and development rate of sprat eggs and larvae (Nissling, 2004; Petereit et al., 2008), no studies have evaluated the impact of salinity. The latter is surprising given that salinity has been shown to be a critical factor influencing the reproductive success of other Baltic Sea fish species, such as Atlantic cod (Gadus morhua), due to the impacts of salinity on egg buoyancy (Nissling and Westin, 1991b).

Recently, Govoni and Forward (2008) reviewed buoyancy patterns of eggs, yolk sac larvae and later larval stages of fish. In marine fish eggs, density (buoyancy) appears to be derived and controlled through passive physiological mechanisms including alteration of constituent compounds within the eggs and, prior to spawning, through developmental events within the ovary (Goarant et al., 2007; Govoni and Forward, 2008 and references therein). It is known that brackish water eggs can have a relatively high ( $>96 \%$ ) water content (e.g. cod, Thorsen et al., 1996) due to increased water uptake during final oocyte maturation (Craik and Harvey, 1987), which is aquaporin-mediated (Fabra et al., 2005). This is caused by a high intracellular content of free amino acid (FAA), chloride anion $\left(\mathrm{Cl}^{-}\right)$and ammonia $\left(\mathrm{NH}_{4}^{+}\right)$, where the high FAA pool is derived from hydrolysis of yolk proteins (Thorsen et al., 1996).
Previous studies have examined the effects of salinity on egg buoyancy and the intrinsic factors impacting egg buoyancy in Baltic Sea fish species. For example, Baltic cod egg mortality and hatching success has been evaluated at different salinities (Nissling and Westin, 1991a), and egg buoyancy has been analyzed in both laboratory experiments and for field samples (Nissling and Westin, 1991b; Nissling et al., 1994a; Nissling and Vallin, 1996; Nissling and Westin, 1997). The effects of different incubation salinities on larval size at hatch, buoyancy, survival, activity-level and feeding ability were assessed from experimental incubation work (Nissling et al., 1994b; Nissling and Vallin, 1996). Nissling et al. (1994a) reported that egg buoyancy in Baltic cod is significantly correlated with yolk osmolality and chorion thickness but only weakly correlated with egg size. In herring (Clupea harengus), a clupeid species that, unlike sprat, spawns benthic eggs, Holliday and Blaxter (1960) compared fertilization rates and osmotic concentrations after fertilization and incubation in salinities ranging from 5.9 to 52.5 . They found higher water content in the perivitelline membrane of eggs incubated at low salinities and related this to the salinity during fertilization. Only a single study has examined sprat egg specific gravity and vertical egg distribution (Nissling et al., 2003); however, to our knowledge no study has been performed on the effects of salinity during fertilization and incubation from the egg phase until the end of yolk sac larval stage in sprat. The present study attempts to fill this gap.

The objectives of the present study were to evaluate the effects of fertilization and/or incubation salinity on the buoyancy, survival and development rate of sprat eggs and the survival and morphometrics of yolk sac larvae. The morphometric traits examined included larval standard length, yolk sac area and body area at hatching, eye-pigmentation (as a proxy for first feeding) and the timing of yolk sac depletion. Our underlying hypotheses were that fertilization and incubation at different salinities will have impacts on i) the duration of the embryonic phase, ii) egg buoyancy and iii) the morphometric traits of yolk sac larvae. To compare experimental results with field samples, sprat egg buoyancy and egg size measurements were performed in spring and early summer 2007 and 2008 at selected stations in the Bornholm Basin, Baltic Sea. 
TABLE 1. - Summary information on salinity experiments conducted on eggs and yolk sac larvae of Baltic sprat from the Bornholm Basin. The symbol + indicates that data were used from this trial for the respective analysis, and the symbol - indicates that no data were available. (n.a. $=$ not applicable)

\begin{tabular}{|c|c|c|c|c|}
\hline \multirow[b]{2}{*}{ Trial } & \multicolumn{2}{|c|}{ Fertilization Trials } & \multirow{2}{*}{$\begin{array}{c}\text { Incubation Trial } \\
3\end{array}$} & \multirow{2}{*}{$\frac{\text { Fertilization Trial }}{4}$} \\
\hline & 1 & 2 & & \\
\hline Year & 2007 & 2007 & 2007 & 2007 \\
\hline \multirow[t]{2}{*}{ Position of sampling } & $55^{\circ} 03.53^{\prime} \mathrm{N}$ & $55^{\circ} 17.10^{\prime} \mathrm{N}$ & $55^{\circ} 18.32^{\prime} \mathrm{N}$ & $55^{\circ} 17.78^{\prime} \mathrm{N}$ \\
\hline & $015^{\circ} 25.21^{\prime} \mathrm{E}$ & $015^{\circ} 20.70^{\prime} \mathrm{E}$ & $015^{\circ} 23.35^{\prime} \mathrm{E}$ & $015^{\circ} 47.23^{\prime} \mathrm{E}$ \\
\hline Date of sampling & $19^{\text {th }}$ April & $21^{\text {st }}$ April & $21^{\text {st }}$ April & $1^{\text {st }}$ June \\
\hline Time of sampling (hours) & 10:00 & $18: 30$ & 23:00 & $22: 30$ \\
\hline No. females/males & $4 / 4$ & $4 / 12$ & $4 / 12$ & $4 / 1$ \\
\hline Eggs per replicate (mean \pm stdev) & $247 \pm 258$ & $226 \pm 144$ & $132 \pm 119$ & $157 \pm 118$ \\
\hline Incubation temperatures (mean \pm stdev) & $6.0 \pm 1.0$ & $6.3 \pm 1.2$ & $6.3 \pm 1.2$ & $8.9 \pm 1.0$ \\
\hline Salinities: & & & & \\
\hline At fertilization $( \pm 0.1)$ & $8,14,20$ & $8,14,20$ & 7.5 & $7,8,9,10$ \\
\hline During incubation $( \pm 0.1)$ & $8,14,20$ & $8,14,20$ & $5,8,11,14,18,30,35$ & n.a. \\
\hline Light regime light/darkness (hours) & $24 / 0$ & $24 / 0$ & $24 / 0$ & $24 / 0$ \\
\hline Replicates (beakers per salinity) & 3 & 3 & 3 & 3 \\
\hline Egg phase: time to hatch & + & + & + & - \\
\hline Egg phase: egg survival & + & + & + & - \\
\hline Egg buoyancy observation & + & + & + & + \\
\hline Yolk sac larvae: size (SL)-at-hatch & + & - & + & - \\
\hline Yolk sac larvae: body area (BA)-at-hatch & + & - & + & - \\
\hline Yolk sac larvae: yolk sac area (YSA)-at-hatch & + & - & + & - \\
\hline Eye pigmentation: SL, BA, YSA & - & - & + & - \\
\hline Yolk sac depletion: SL, BA, YSA & + & - & - & - \\
\hline
\end{tabular}

\section{MATERIALS AND METHODS}

In total, 4 different trials of experiments were conducted. Three of these trials (trials 1,2 and 4) used different salinities during the egg fertilization and incubation process and therefore are labeled "fertilization trials". In one trial (trial 3) eggs were fertilized at one salinity and immediately separated into different incubation salinities; this trial is labeled "incubation trial". Salinity was measured in practical salinity units (psu) and values are presented as a dimensionless parameter. Details on locations, sampling times and abiotic conditions are listed in Table 1. Sprat were caught by pelagic trawl (Engel Combi Trawl, codend mesh size: $10 \mathrm{~mm}$ ) in the Bornholm Basin, Baltic Sea, during cruises of the RV "Alkor" in mid April and June 2007. For numbers of females/ males used in each trial see Table 1 .

Eggs were manually stripped and collected within a test tube and then distributed in equal amounts among three test tubes containing tempered artificial seawater (Aquarium Brand) of defined salinities (see Table 1). One droplet of semen was transferred with a pipette into each of the tubes and gently stirred. Eggs at each experimental salinity were subsequently decanted into three replicate beakers containing $150 \mathrm{ml}$. The same method was used for trials 1, 2 and 4, but eggs from trial 4 were only used for density observations.
Unlike the above mentioned trials, eggs in trial 3 were activated in a beaker containing $1 \mu \mathrm{m}$ filtered Baltic seawater with a salinity of 7.5. Within 5 min after activation, eggs were gently and randomly decanted into three replicate glass beakers containing $150 \mathrm{ml}$ of $6^{\circ} \mathrm{C}$ artificial seawater with salinities of $5,8,11,14,18,30$, and 35. Fertilization success was not directly measured prior to loading eggs into replicate beakers. The egg phase was defined as the period from semen activation (at contact with the eggs) until hatching of the larvae from the chorion, and determined cumulative egg survival during that whole period. Dead (changing color from transparent to pale white) and unfertilized eggs (showing no clear cell divisions) were removed with a pipette and a minimum of $1 / 3$ of the water from each beaker was changed daily.

Eggs were staged following the scheme presented by Thompson et al. (1981), which was modified due to early hatching at the end of stage IV by sprat in the Baltic Sea. Every 24 h subsamples of eggs (1 to 2 per replicate) were checked for developmental stage at $16 x$ magnification. Due to the low overall number of eggs per trial, eggs were returned to their respective beakers after staging (within <20 s). The temperature controlled laboratory on the RV "Alkor" had to be illuminated for $24 \mathrm{~h}$ and this photoperiod was continued at the institute's laboratory. 


\section{Egg buoyancy}

For trials 1, 2 and 3 the positions of the eggs within the glass beakers were visually determined each day and categorized (bottom, floating, surface). In addition, (for trials 1 and 3 ) densities of three eggs (at developmental stage III) per salinity treatment (one egg per replicate) were determined in a salinity gradient column (Coombs, 1981; Nissling et al., 2003). The positions of the eggs in the column were compared with the positions of 4 density floats of known specific gravity (correlation coefficient of the calibration floats $>0.99$ ) at $6^{\circ} \mathrm{C}$ in a temperature controlled laboratory.

Each egg at stage I from trial 4 was placed at $8.9^{\circ} \mathrm{C}$ in a new beaker which contained filtered seawater of the respective fertilization salinity. For trials with salinity of 7 and 8 , water of higher salinity was gently poured with a pipette as long as eggs were laying on the bottom of the beaker and was immediately stopped when eggs came off the bottom. At a given temperature and known salinity conditions (measured by a calibrated salinometer (WTW instruments \pm 0.1 psu error) it is possible to calculate the accurate density of the seawater sample (Fofonoff and Millard, 1983). These calculations were performed after the eggs attained neutral buoyancy in the beaker for at least $60 \mathrm{~min}$. For the 9 and 10 salinity treatments, lower salinity water was first added since eggs were already floating near the surface. Once the eggs had sunk, higher salinity water was utilized as described above.

\section{Field sampling}

Eggs were caught by either a WP-2 plankton net $(60 \mathrm{~cm}$ diameter, $200 \mu \mathrm{m}$ mesh size) or 'Helgoländer Larven Netz' (HLN, $143 \mathrm{~cm}$ diameter, 300 $\mu \mathrm{m}$ mesh size) towed vertically from $5 \mathrm{~m}$ above the bottom (68 to $95 \mathrm{~m}$ bottom depth depending on the station) to the surface. Eggs were immediately sorted from samples with $3 \mathrm{~mm}$ diameter pipettes and staged. Egg diameter was measured to the nearest scale bar below $(0.1 \mathrm{~mm}$ or $0.06 \mathrm{~mm})$ at $10 x$ or $16 x$ magnification, and thus the highest possible resolution of size classes was guaranteed. On some cruises, ship movements required a change in resolution. For this reason, only eggs within the same broad size class (small, 1.26 to $1.38 \mathrm{~mm}$; medium, 1.39 to $1.51 \mathrm{~mm}$; large, 1.52 to $1.64 \mathrm{~mm}$ ) were compared among different sampling dates.
TABLE 2. - Summary information for sprat egg field sampling conducted in the Bornholm Basin, Baltic Sea. The symbol + indicates cruises with successful artificial fertilization experiments, not applicable (n.a.) in 2008. See text for gears employed.

\begin{tabular}{|c|c|c|c|c|c|c|}
\hline Cruise & Year & Date & Gear & $\begin{array}{l}\text { Experimental } \\
\text { Trial }\end{array}$ & $\begin{array}{l}\text { Stations } \\
\text { (n) }\end{array}$ & $\begin{array}{l}\text { Eggs } \\
\text { (n) }\end{array}$ \\
\hline Al 297 & 2007 & $14 .-15.04$ & HLN + WP2 & + & 1 & 3 \\
\hline Al 297 & 2007 & 11.04 & Multinet & & 1 & 5640 \\
\hline Al 299 & 2007 & 27.05 & HLN + WP2 & + & 1 & 23 \\
\hline Al 299 & 2007 & 27.05 & Multinet & & 1 & 17015 \\
\hline $\mathrm{Al} 318$ & 2008 & 14.-15.04 & HLN & n.a. & 3 & 31 \\
\hline Al 320 & 2008 & 1.-6.06 & HLN & n.a. & 9 & 520 \\
\hline
\end{tabular}

The number of stations sampled and eggs measured differed between cruises (Table 2). Whereas in April 2008 just three stations in the Bornholm Basin could be analyzed ( 31 eggs) the May/June 2008 cruise ( 9 stations, 520 eggs) covered the northern, central and southern parts of the Bornholm Basin and yielded about 20 to 30 eggs per size class for density-measurements (see above). The depth at which each egg would have had potential density equilibrium was calculated from temperature, salinity, oxygen, and sigma-t profiles measured using a CTD (ADM- company) at each station.

In April and May/June 2007 repeated Multinet hauls (MN, $335 \mu \mathrm{m}$ mesh size, $0.5 \mathrm{~m}^{2}$ net opening, $5 \mathrm{~m}$ depth interval) were performed at the HLN and WP-2 stations and analyzed for egg vertical distribution (Haslob et al., 2007; Harjes, 2008). The experimentally derived egg buoyancy data set from May/ June 2007 was back calculated to the potential vertical distribution (depth in meters) which compared well to the observed egg vertical distribution from Multinet samples (Table 2, Harjes, 2008). Since the sample size of buoyancy measured eggs for April 2007 was too small to cover the whole possible range in depths, we employed the vertical egg distribution derived from Multinet samples (between 50 and $70 \mathrm{~m}$ depth where $>90 \%$ of eggs were located; from Harjes, 2008). Temperature and salinity profiles from CTD casts were used to calculate density (sigma- $t$ ) values in the depth range of the observed vertical egg distribution.

\section{Larval morphometrics}

Larval morphometrics were analyzed for experimental trials 1 and 3. From each salinity treatment, 8 to 19 larvae were randomly sampled at peak-hatch. At eye pigmentation (EP, as a proxy for mouth gape opening) at day 9, (trial 3) and yolk sac depletion 
(YSD) at day 11 (trial 1) sample sizes had to be reduced due to low numbers of remaining larvae. Results at salinities of 30 and 35 were excluded from the analyses since larval mortality was high (only a single larva survived per treatment).

Larvae were placed on a micrometer scale $(1 / 10$ $\mathrm{mm}$ scale parts) and photographed under a stereomicroscope (WILD M3Z) equipped with a digital camera system (Canon Ixus Digital Camera). Morphometric measurements and determination of EP and YSD were based on larval images, the YSD was based on $<5 \%$ of original yolk sac area remaining. Standard length (SL, mm) was measured from the tip of the mouth until the end of the urostyl. The yolk sac area (YSA, $\mathrm{mm}^{2}$ ) and body area (BA, $\mathrm{mm}^{2}$, excluding larval finfolds) were determined by tracing and integrating the area with image analysis software (Image Tool 3.0; http://ddsdx.uthscsa.edu/ dig/download.html).

\section{Statistics}

All statistical analyses were performed using the programs STATISTICA, STATeasy and SigmaPlot. No statistical tests were applied to compare egg development durations, durations to $\mathrm{EP}$ and time to yolk sac depletion since all larvae reached the respective development stage in all respective salinities on the same sampling day. A two-way (trial x salinity) ANOVA was applied to compare egg survival rates between trial 1 and 2. Although marginal deviations from the homogeneity of variances (Cochran test) were detected, irrespective of the data transformation procedure, normal distribution assumptions were ac- cepted. As a consequence, egg survival of each trial was also compared by one-way ANOVAs separately to test for differences among salinities. Fertilization experiment egg buoyancy values, egg size class density values and larval morphometric traits (SL, YSA, BA) were compared among salinity treatments by one-way factorial ANOVAs, after meeting the assumptions of variance homogeneity (Levene's or Hartley F-max test) and normality (Shapiro Wilks W test). When significant differences were detected, a Tukey HSD test was applied. Egg density values (all egg size classes pooled) were compared for April and May versus June 2008 using a Mann Whitney U-test.

\section{RESULTS}

\section{Egg phase}

\section{Egg development and survival}

Egg development time (from fertilization until hatching) was unaffected by fertilization salinity and was 9 days at 6.0 to $6.3^{\circ} \mathrm{C}$ for all salinities (Table 3). Survival from fertilization to hatch was influenced by salinity in fertilization trial 2 ( $\mathrm{p}=0.0007$, Fig. 1a, Tables 3 and 4). Survival was significantly lower at a salinity of 8 compared to survival at salinities of 14 and 20 (Tukey HSD, p=0.001). Survival of eggs in trial 1 was significantly higher than in trial $2(\mathrm{p}<0.05)$. In trial 3, no eggs survived at the lowest incubation salinity (5) but survival was not significantly different at salinities between 8 and 35 ( $\mathrm{p}=0.95$; Fig. 1b, Tables 3 and 4).

TABLE 3. - Mean egg survival rates and time durations to important events during sprat egg and yolk sac stage. For each trial, bold labeled numbers of survival indicate significant differences $(\mathrm{p}<0.01)$ among salinities and different superscript letters indicate which ones differ. $\mathrm{N}$ is the number of independent replicates (beakers) per salinity treatment. "n.d." denotes not determined.

\begin{tabular}{|c|c|c|c|c|c|c|}
\hline Trial & Salinity & $\mathrm{n}$ & $\begin{array}{l}\text { Egg survival }(\%) \\
\text { mean } \pm \text { stdev }\end{array}$ & $\begin{array}{l}\text { Duration (days) } \\
\text { Fertilization to hatching }\end{array}$ & $\begin{array}{c}\text { Duration (days) } \\
\text { Hatching to } \\
\text { eye pigmentation }(\mathrm{EP})\end{array}$ & $\begin{array}{c}\text { Duration (days) } \\
\text { Hatching to yolk } \\
\text { sac depletion (YSD) }\end{array}$ \\
\hline 1 & 8 & 3 & $6.08 \pm 6.91$ & 9 & n.d. & 11 \\
\hline 1 & 14 & 3 & $21.45 \pm 11.34$ & 9 & n.d. & 11 \\
\hline 1 & 20 & 3 & $12.15 \pm 2.98$ & 9 & n.d. & 11 \\
\hline 2 & 8 & 3 & $0.42 \pm 0.48^{a}$ & 9 & n.d. & n.d. \\
\hline 2 & 14 & 3 & $3.41 \pm 0.50^{\mathrm{b}}$ & 9 & n.d. & n.d. \\
\hline 2 & 20 & 3 & $3.43 \pm 0.63^{\mathrm{b}}$ & 9 & n.d. & n.d. \\
\hline 3 & 5 & 3 & 0 & no hatch & - & - \\
\hline 3 & 8 & 3 & $7.77 \pm 5.34$ & 9 & 9 & n.d. \\
\hline 3 & 11 & 3 & $8.26 \pm 3.89$ & 9 & 9 & n.d. \\
\hline 3 & 14 & 3 & $9.87 \pm 4.52$ & 9 & 9 & n.d. \\
\hline 3 & 18 & 3 & $10.43 \pm 4.42$ & 9 & 9 & n.d. \\
\hline 3 & 30 & 3 & $7.80 \pm 4.71$ & 9 & 9 & n.d. \\
\hline 3 & 35 & 3 & $8.38 \pm 1.18$ & 9 & 9 & n.d. \\
\hline
\end{tabular}



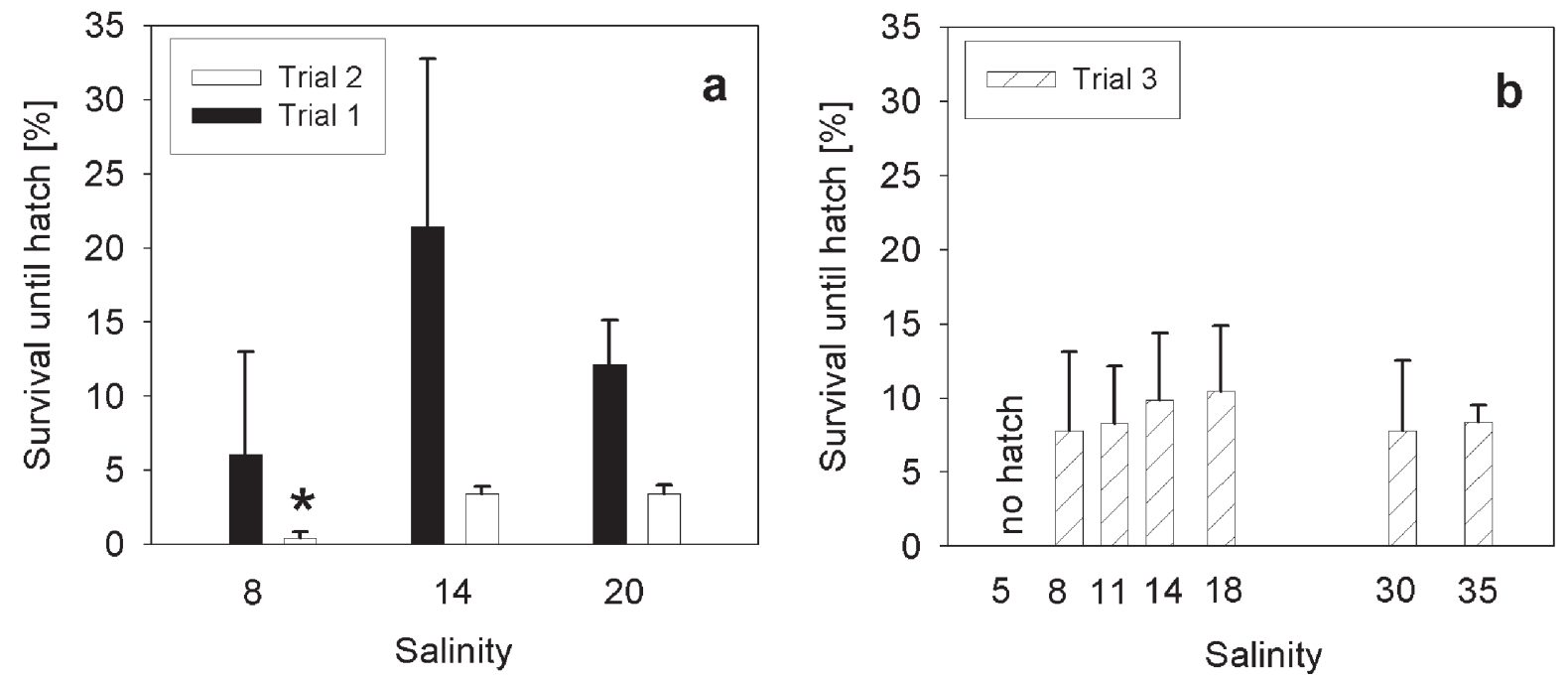

FIG. 1. - Mean (+SD) egg survival from fertilization to hatch versus salinity ( $n=3$ replicate beakers, each with $>130$ eggs). (a) Survival of eggs fertilized and incubated at different salinities, an asterisk marks a significant difference between salinities in trial 2, (b) survival of eggs fertilized at a salinity of 7.5 and subsequently $(<5 \mathrm{~min})$ incubated at different salinities.

Egg buoyancy derived from fertilization/incubation experiments

Irrespective of fertilization salinity $(7.5,8,14$, 20 ), eggs were buoyant at salinities $\geq 14$. At 14 approximately $50 \%$ of the eggs were floating in the midwater and $50 \%$ in the surface layer. At salinities of 5, 8 and 11, eggs were on the bottom and at 18, 20, 30 and 35, eggs floated in the surface layer.

Experimental sprat egg buoyancy values (egg stage III, Table 5) in April 2007 differed significant- ly between salinity levels 8 and $14(\mathrm{p}<0.05)$, and between 8 and $20(\mathrm{p}<0.006)$. The buoyancy decreased with increasing fertilization salinity (Fig. 2a) and was best described for the fertilization salinity trials by a linear function (Table 6). This increasing trend was also visible after fertilization at salinity 7.5 and immediate $(<5 \mathrm{~min}$ after egg activation) transfer to higher saline incubation conditions in trial 3 (Fig. $2 \mathrm{a}$ ); however, in this case, was best described by a non-linear function (Table 6). For both fertilization/ incubation datasets, the effect of salinity on egg den-
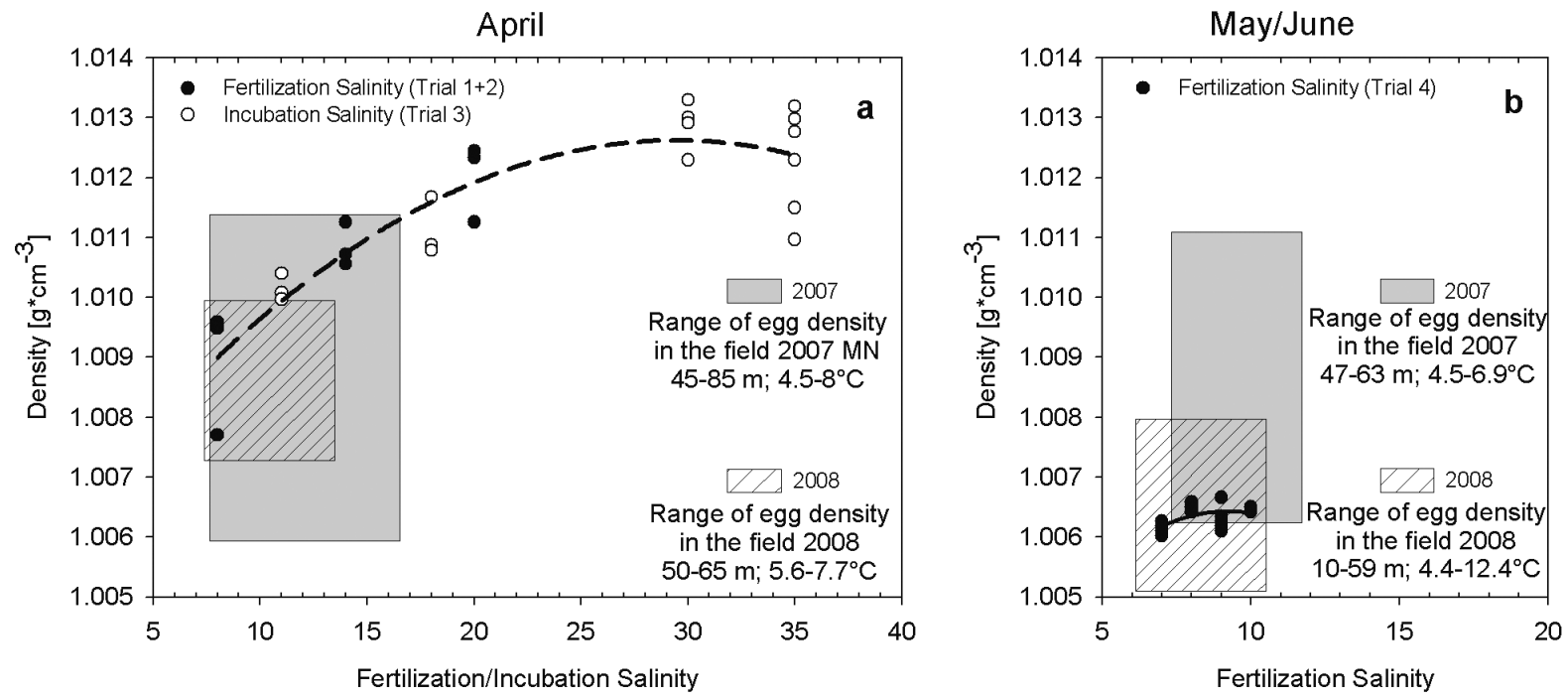

FIG. 2. - Values of sprat egg density versus salinity derived for trials conducted in April (Panel A) and May/June (Panel B). Filled points (data from trials 1,2 and 4), unfilled points = trial 3. Each point represents a density value of a single egg from an independent replicate, except at salinity 30 and 35, where more than one egg was tested per replicate. The non-linear regressions (heavy dashed line) describe all laboratory data displayed in a panel. Box areas (grey=2007; lined=2008) indicate the range of egg densities and salinities of field sampled eggs (see text for details). 
TABLE 4. - Statistical results of the analysis of egg survival, egg buoyancy from experimental and field data and morphometric traits of sprat. Relative egg sizes refer to unpreserved, live eggs and were between 1.26 and $1.38 \mathrm{~mm}$ for small, 1.39 and $1.51 \mathrm{~mm}$ for medium and 1.52 and $1.64 \mathrm{~mm}$ for large eggs. Larval morphometric traits are measured at three important ontogenetic events (hatch, eye pigmentation (EP) and yolk sac depletion (YSD)). SL is standard length, YSA refers to yolk sac area and BA describes larval body area excluding larval finfolds. Significant differences between salinities are contrasted in bold color.

\begin{tabular}{|c|c|c|c|c|c|c|}
\hline \multirow{2}{*}{$\begin{array}{l}\text { Parameters } \\
\text { Egg survival }\end{array}$} & \multirow[t]{2}{*}{ Trial } & & & \multirow[t]{2}{*}{ Statistical test } & \multirow[t]{2}{*}{$\mathrm{F}$} & \multirow[t]{2}{*}{$\mathrm{p}$} \\
\hline & & \multicolumn{2}{|c|}{ Egg developmental period } & & & \\
\hline & $\begin{array}{c}1 \\
2 \\
3 \\
1+2 \\
1+2\end{array}$ & \multicolumn{2}{|c|}{$\begin{array}{l}\text { fertilization - hatch } \\
\text { fertilization - hatch } \\
\text { fertilization - hatch } \\
\text { fertilization - hatch } \\
\text { fertilization - hatch }\end{array}$} & $\begin{array}{c}\text { one way ANOVA } \\
\text { one way ANOVA } \\
\text { one way ANOVA } \\
\text { two way ANOVA, trial } \\
\text { two way ANOVA, salinity }\end{array}$ & $\begin{array}{c}\mathrm{F}_{2,6}=2.91 \\
\mathrm{~F}_{2,6}=30.78 \\
\mathrm{~F}_{5,12}=0.21 \\
\mathrm{~F}_{1,12}=16.96 \\
\mathrm{~F}_{2,12}=4.07\end{array}$ & $\begin{array}{c}0.130 \\
\mathbf{0 . 0 0 0 7} \\
0.950 \\
<\mathbf{0 . 0 5} \\
>0.05\end{array}$ \\
\hline \multicolumn{2}{|c|}{$\begin{array}{l}\text { Egg buoyancy / density } \\
\text { EXPERIMENT }\end{array}$} & \multicolumn{2}{|l|}{ Salinity } & & & \\
\hline & $\begin{array}{c}1 \\
3 \\
1+3 \\
4\end{array}$ & \multicolumn{2}{|c|}{$\begin{array}{c}8-14-20 \\
11-18-30-35 \\
8-11-14-18-20-30-35 \\
7-8-9-10\end{array}$} & $\begin{array}{l}\text { one way ANOVA } \\
\text { one way ANOVA } \\
\text { one way ANOVA } \\
\text { one way ANOVA }\end{array}$ & $\begin{array}{l}\mathrm{F}_{2,6}=12.99 \\
\mathrm{~F}_{3,12}=12.49 \\
\mathrm{~F}_{6,18}=13.88 \\
\mathrm{~F}_{3,20}=11.87\end{array}$ & $\begin{array}{c}0.007 \\
0.0005 \\
0.0001 \\
0.001\end{array}$ \\
\hline \multirow[t]{2}{*}{ FIELD } & & \multicolumn{2}{|l|}{ Egg size } & & & \\
\hline & $\begin{array}{c}\text { May/June } 2007 \\
\text { April } 2008 \\
\text { June } 2008 \\
\text { April 2008 vs } \\
\text { May/June 2008 }\end{array}$ & \multicolumn{2}{|c|}{$\begin{array}{l}\text { small-medium-large } \\
\text { small-medium-large } \\
\text { small-medium-large }\end{array}$} & $\begin{array}{l}\text { one way ANOVA } \\
\text { one way ANOVA } \\
\text { one way ANOVA }\end{array}$ & $\begin{array}{c}\mathrm{F}_{2,20}=0.2611 \\
\mathrm{~F}_{2,28}=0.273 \\
\mathrm{~F}_{2,517}=39.38\end{array}$ & $\begin{array}{c}0.77 \\
0.97 \\
\mathbf{0 . 0 0 0 1}\end{array}$ \\
\hline Larval morpl & etric traits & Morphometric trait & Time (days) & & & \\
\hline & $\begin{array}{l}1 \\
1 \\
1 \\
1 \\
1 \\
1 \\
3 \\
3 \\
3 \\
3 \\
3 \\
3\end{array}$ & $\begin{array}{l}\text { SL - Hatch } \\
\text { SL - YSD } \\
\text { YSA - Hatch } \\
\text { YSA - YSD } \\
\text { BA - Hatch } \\
\text { BA - YSD } \\
\text { SL - Hatch } \\
\text { SL - EP } \\
\text { YSA - Hatch } \\
\text { YSA - EP } \\
\text { BA - Hatch } \\
\text { BA - EP }\end{array}$ & $\begin{array}{c}0 \\
11 \\
0 \\
11 \\
0 \\
11 \\
0 \\
9 \\
0 \\
9 \\
0 \\
9\end{array}$ & $\begin{array}{l}\text { one way ANOVA } \\
\text { one way ANOVA } \\
\text { one way ANOVA } \\
\text { one way ANOVA } \\
\text { one way ANOVA } \\
\text { one way ANOVA } \\
\text { one way ANOVA } \\
\text { one way ANOVA } \\
\text { one way ANOVA } \\
\text { one way ANOVA } \\
\text { one way ANOVA } \\
\text { one way ANOVA }\end{array}$ & $\begin{aligned} \mathrm{F}_{2,37} & =2.36 \\
\mathrm{~F}_{2,33} & =0.84 \\
\mathrm{~F}_{2,33} & =31.79 \\
\mathrm{~F}_{2,33} & =2.79 \\
\mathrm{~F}_{2,37} & =2.06 \\
\mathrm{~F}_{2,33} & =2.36 \\
\mathrm{~F}_{5,83} & =4.53 \\
\mathrm{~F}_{3,24} & =1.01 \\
\mathrm{~F}_{5,84} & =30.40 \\
\mathrm{~F}_{3,24} & =2.20 \\
\mathrm{~F}_{5,85} & =1.71 \\
\mathrm{~F}_{3,24} & =2.44\end{aligned}$ & $\begin{array}{c}0.10 \\
0.43 \\
\mathbf{0 . 0 0 0 1} \\
0.07 \\
0.140 \\
0.86 \\
\mathbf{0 . 0 0 1} \\
0.40 \\
\mathbf{0 . 0 0 0 1} \\
0.11 \\
0.14 \\
0.08\end{array}$ \\
\hline
\end{tabular}

sity values was best described using a second-order polynomial function (Fig. 2a, Table 6). During the June experiments, egg density (stage I) significantly increased with increasing salinity (Fig. 2b, Table 5).

\section{Egg buoyancy derived from field samplings}

Egg density $\left(\mathrm{g}^{*} \mathrm{~cm}^{-3}\right)$ ranged from 1.0060 to 1.0110 in April 2007 and from 1.0072 to 1.0112 in May/June 2007 with a mean of 1.0090 in both months (Fig. 2a, b, grey boxes, Table 5). The egg density had a narrower distribution in April 2008 compared to April 2007 (Fig. 2a, Table 5) but mean values were similar between years. Later in the season (May/June 2008), egg density was between 1.0051 and 1.0080, the lowest density (=highest buoyancy) observed in this study (Fig. 2b, Table 5). Mean egg density was significantly higher in April than in June 2008 (Table 4).
Comparison of field caught eggs versus experimentally derived egg densities resulted in an overlap with buoyancies from fertilization/incubation salinities of 8, 11 and 14 in April 2007 (Fig. 2a, grey box); however, this overlap was low for eggs which were incubated at salinities of 8 and 11 in April 2008 (Fig. 2a, lined box). A high overlap between laboratory- and field-derived egg densities was observed during May/June 2008 (Fig. 2b, shaded box), but no overlap was observed in 2007; higher density values were obtained in field-sampled eggs (Fig. 2b, grey box).

\section{Egg size effect on buoyancy}

There was no significant difference in mean egg buoyancy among the three egg size classes in May/ June 2007 and April 2008 but all three size classes were significantly different from one another in 


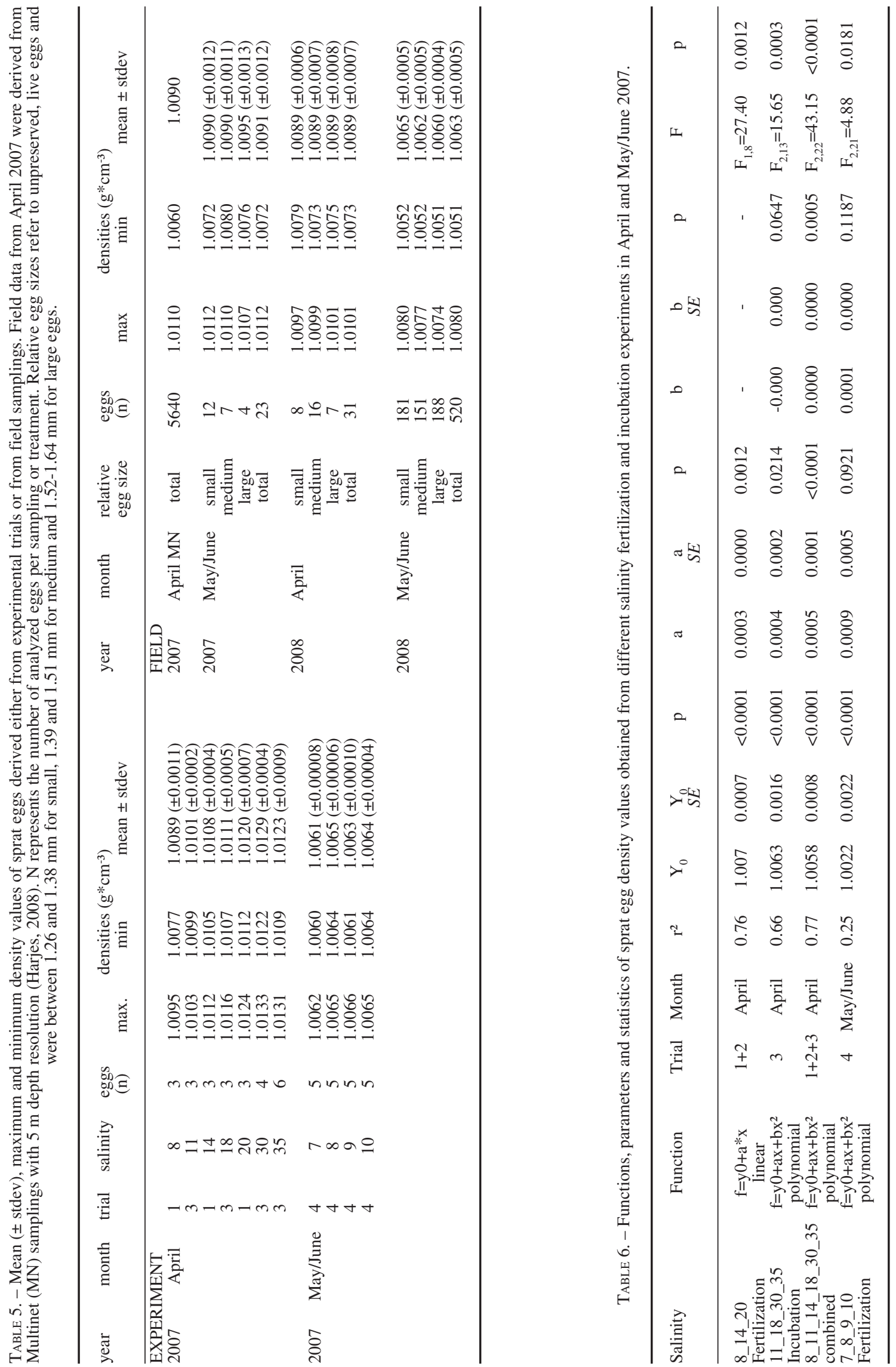



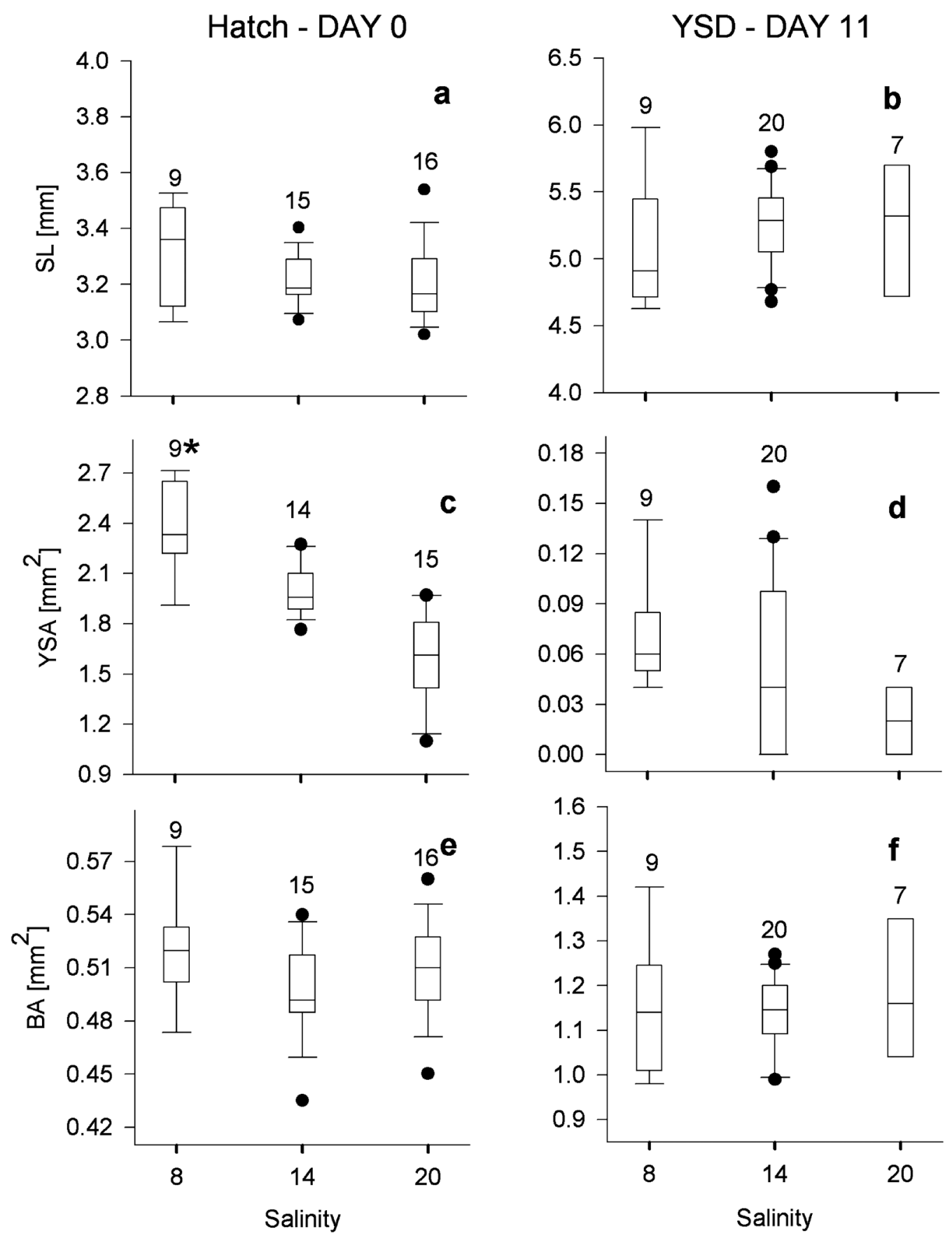

FIG. 3. - Yolk sac larval morphometric traits (standard length (SL, mm), yolk sac area (YSA, $\mathrm{mm}^{2}$ ) and body area $\left(\mathrm{BA}, \mathrm{mm}^{2}\right)$ ) of Baltic Sea sprat larvae originating from the fertilization trial (trial 1), at hatch (Day 0, left panels a, c, e) and at yolk sac depletion (YSD -Day 11, right panels $b, d, f)$. Box-Whisker plots show the median as a black bar, the $25^{\text {th }}$ and $75^{\text {th }}$ percentiles as vertical boxes with the $10^{\text {th }}$ and $90^{\text {th }}$ percentiles as error bars. Numbers of measured larvae are presented above each Whisker. Asterisks mark significant differences between salinities.

May/June 2008 (Table 4). Differences in the density of field-sampled eggs corresponded to differences in the abiotic conditions as revealed by CTD measurements, i.e. mean temperatures of $5.3^{\circ} \mathrm{C}$, $6.0^{\circ} \mathrm{C}$ and $6.3^{\circ} \mathrm{C}$ and salinities of $8.3,8.05$ and 7.85 for the small, medium and large size classes respectively.

\section{Larval phase}

Morphometric traits of larvae fertilized and reared under different salinities

Larval SL was not significantly different among the salinity treatments, neither at hatch $(p>0.1)$ nor 

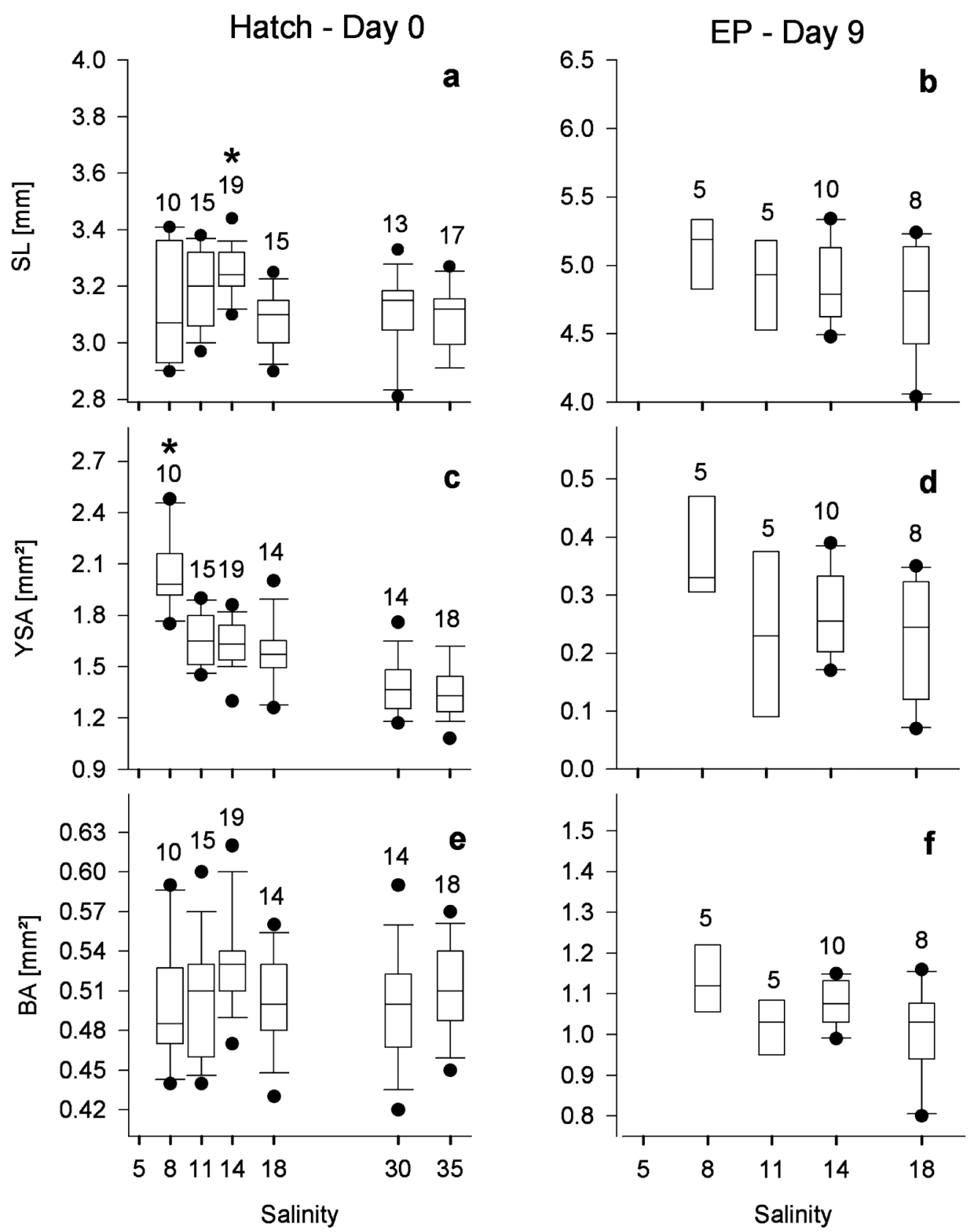

FIG. 4. - Yolk sac larval morphometric traits (standard length (SL, mm), yolk sac area (YSA, $\mathrm{mm}^{2}$ ) and body area $\left(\mathrm{BA}, \mathrm{mm}^{2}\right)$ ) of Baltic Sea sprat larvae originating from the incubation trial (trial 3), at hatch (Day 0, left panels a, c, e) and at eye pigmentation (EP- Day 9, right panels $\mathrm{b}, \mathrm{d}, \mathrm{f}$ ). Box-Whisker plots show the median as a black bar, the $25^{\text {th }}$ and $75^{\text {th }}$ percentiles as vertical boxes with the $10^{\text {th }}$ and $90^{\text {th }}$ percentiles as error bars. Numbers of measured larvae are presented above each Whisker. Values at EP at salinities of 30 and 35 were excluded in b, $d$ and f. due to high mortalities. An asterisk marks a significant difference between salinities.

at YSD on day 11 (p>0.4) (Figs. 3a, b and Table 4). However, YSA at hatch was significantly different between salinity treatments with the largest mean $\pm \mathrm{SE}\left(2.37 \pm 0.26 \mathrm{~mm}^{2}\right)$ area at a salinity of 8 . On day 11 , YSA was reduced to less than $5 \%$ of the original area-at-hatch and did not differ significantly $(\mathrm{p}=0.07)$ between the salinity groups (Fig. 3d). BA was not significantly affected by salinity at hatch $(\mathrm{p}>0.1)$ or at yolk depletion ( $p>0.8$ ) on day 11 (Figs. 3e, f).

\section{Morphometric traits of larvae fertilized together then reared under different salinities}

Larval SL at hatch was largest at a salinity of 14 $(3.24 \pm 0.09 \mathrm{~mm})$ compared to 18 and 35 (Fig. $4 \mathrm{a}$ and for statistical comparisons see Table 4). This significant difference in larval length $(\mathrm{p}=0.001)$ was not observed at EP on day 9 (Fig. 4b). YSA was significantly affected by salinity $(\mathrm{p}=0.0001)$, where the 
YSA of larvae incubated at $8(2.04 \pm 0.2 \mathrm{~mm})$ was significantly greater than that at all other salinities (Fig. 4c). No significant differences in YSA were observed among larval groups at salinities of 11, 14 and 18, and among those at 30 and 35 . However, at EP yolk reserves of surviving larvae did not differ significantly $(\mathrm{p}=0.11)$ among treatments (Fig. $4 d$ ). BA (Fig. 4e) did not significantly differ at hatch $(\mathrm{p}=0.14)$. At $\mathrm{EP}, \mathrm{BA}$ was largest at $8(1.13 \pm 0.09$ $\mathrm{mm})$ and tended to decrease $(\mathrm{p}=0.088)$ with increasing salinity (Fig. 4f).

\section{DISCUSSION}

\section{Egg development duration and survival}

An egg development duration of 9 days at $6^{\circ} \mathrm{C}$ agreed well with values (9.5 and 9.2 days) reported by Petereit et al. (2008) for Baltic sprat eggs incubated at similar temperatures $\left(6^{\circ} \mathrm{C}\right.$ and $\left.6.3^{\circ} \mathrm{C}\right)$ and fertilized (incubated) at a salinity of 7.1 (14.8). That hatching time is independent of salinity corresponds with the majority of published reports (review paper by Kamler, 2002). In contrast, Holliday and Blaxter (1960) found a two-day retardation to peak-hatch in herring at salinities of 5.9 and 11.5 compared to salinities of 22 to 45. Laurence and Howell (1981) stated that "it is hard to attach any significance in an ecological sense to differences spanning only 0.6 days", which they found as a statistically significant result of accelerated egg development at increased salinity (range 28 to 38 ) in yellowtail flounder (Limanda ferruginea). However, for the situation of sprat in the Central Baltic Sea, reduced egg development time could be beneficial for survival due to a high predation pressure on eggs by clupeids (Köster and Möllmann, 2000). Sprat eggs in this study were also incubated in salinity conditions exceeding the natural range experienced in the central Baltic Sea (30 and 35), but development time remained the same in all experiments. This implies that mainly other factors such as temperature, oxygen or egg size control the duration of embryonic development. However, there may also be a direct effect of salinity on egg survival, which could be relevant for recruitment.

Egg survival differed significantly between fertilization trials 1 and 2, indicating that the conditions were different in some unknown way; however, in both trials mean egg survival was lower at a salin- ity of 8 compared to salinities of 14 and 20 . Though a corresponding effect was not obvious in trial 3 at salinities ranging from 8 to 35 , there might be a trend to higher survival at salinities $>8$, probably with a peak around 14 to 18 , but confirmation from further experiments is required. For the situation in the Central Baltic this would imply a higher egg survival in deeper water masses compared to less saline, intermediate water layers or on the slopes of deep basins where spawning occurs. A salinity of 5, however, did not lead to completion of egg development. These eggs were fertilized at a higher salinity, and the question remains open of whether successful fertilization can occur at such low salinities. Sperm motility experiments, using 8 male sprat captured in the Bornholm Basin, revealed that only 2 of them produced viable sperm at salinities of 5 (Petereit, unpublished data). In any case, even if eggs were fertilized at a salinity of 5, no larvae would survive from these eggs (Sjöblom and Parmanne, 1980).

Egg survival can also be influenced by low egg buoyancy. Sprat eggs are assumed to have a minimum buoyancy limit at a salinity of 6 (Kändler, 1941) or 6.5 (Hempel, 1979). This implies that eggs would sink to the bottom and die if water salinity fell below this threshold. At the present time, salinities $\leq 5$ are very unlikely to occur on the main spawning grounds of sprat in the Central Baltic Sea, but a tendency towards lower salinity may be expected in the future (BALTEX, 2006).

The importance of abiotic factors on egg buoyancy after release of the eggs from the ovary into water has been questioned. Hempel (1979) stated that incubation salinity (via perivitelline water) does not contribute to the buoyancy of the eggs in general. This is supported by Nissling et al., (2003) who found no significant difference in egg specific gravity in fertilization experiments with Baltic Sea sprat eggs at salinities of 10 and 15 . However, our study showed clear positive relationships $\left(r^{2}>0.75\right)$ of increased egg density resulting from increased fertilization (and incubation) salinity, at least for the April situation, indicating that salinity as a factor cannot be neglected. Density adjustments of typical teleost eggs after they have been transferred to markedly different salinities have been described earlier (Jacobsen and Johansen, 1908; Kändler and Tan, 1965). A mechanistic explanation based on the permeability of the chorion for water and salts is given by Alderdice (1988). Egg swelling continues as water and ions enter the forming perivitelline 
fluid until a steady state ensues between the chorion and the increasing hydrostatic pressure (Alderdice, 1988). The change in neutral buoyancy of the eggs has been estimated as corresponding to approximately 2 practical salinity units at a change in ambient salinity of 10 practical salinity units (Coombs et al., 1985), which agrees well with the results of the present study.

In principle, the observed differences in buoyancy could also have been derived from differences in egg size. An inverse relation between egg size and egg density has been shown by Nissling et al. (2003) for Baltic Sea sprat eggs. Our results from field samples in May/June 2007 and April 2008 did not support an inverse relation between egg size and egg density; but the May/June 2008 situation revealed a size effect on egg buoyancy. At that time, sampling was performed at 9 stations covering northern, central and southern stations in the Bornholm Basin. In 8 of 9 stations, there was a trend of increased buoyancy with increased egg size. But at two stations, egg buoyancy of the smallest eggs was almost identical to medium and large sized eggs. However, this could neither be related to spatial aspects (the northern versus the southern part of the basin) nor to bottom depth (71 $\mathrm{m}$ and $89 \mathrm{~m}$ respectively) and was not consistent with salinity variations at the different stations. Maternal effects could contribute to the observed patterns, but this was not found in two of the three events. Thus, a sampling effect cannot be excluded and may have influenced the result in May/ June 2007, when only one station was sampled. Otherwise, eggs utilized in experiments originated from several sprat females, but all eggs were pooled and mixed before they were distributed to the respective fertilization/incubation salinities. Thus, we could exclude the potential effect of egg size on the observed density increase with increased incubation salinity at least for the experimental results, but we could not quantify within this study how much individual egg size derived by either maternal effects or batch number contributes to the observed results.

In addition, a clear seasonal difference in egg buoyancy could be observed in April and May/ June 2008 concurrent with the progressing spawning season. The cause of the seasonal phenomenon is not sufficiently understood to date (Nissling et $a l ., 2003)$. This effect might be partly explained by marked differences observed in the vertical distribution of sprat in the course of the spawning season as derived from hydro acoustic survey data (Stepputtis,
2006). This also modifies the ambient salinity conditions for egg fertilization. The residence depth of sprat (weighted mean depth) decreased from 60-80 $\mathrm{m}$ (halocline and below) in March /April to 40-70 $\mathrm{m}$ (halocline, intermediate water layer) in May and to 20-60 m (upper halocline, intermediate and surface layers) in June to August (Daniel Stepputtis, unpublished data). This means that, at least during daytime, sprat experienced higher and then lower salinities during the spawning season (e.g. in 2007 April 12-17; May 8-15; August 7.3-11). Spawning of Baltic sprat does not seem to be restricted only to nighttime or darkness (Holger Haslob, unpublished data), which supports previous reports of continuous spawning during daytime (Alekseev and Alekseeva, 2005). It is possible therefore that sprat could spawn and eggs would be activated at relatively high salinities occurring within the halocline and deep water layers and at progressively lower salinities as the spawning season progresses. Spatial variation in egg density has been described for eggs of Bay of Biscay anchovy (Engraulis encrasicolus) where egg density increased with increased sea surface salinity (Goarant et al., 2007). For other Baltic species like cod, plaice (Pleuronectes platessa), flounder (Platichthys flesus) and dab (Limanda limanda) Hohendorf (1968) performed micro measurements of the concentration of blood, urine and ovarian fluid in a decreasing salinity gradient (from west to east in the Baltic Sea). He found a significant decrease in ovarian fluid concentration and a slight increase in blood concentration from west to east. He concluded that the final adaptation of the specific gravity of the pelagic eggs to the outer medium took place during spawning in seawater in the phase of activation. To our knowledge there is no information on blood or adult body fluid concentrations of sprat available which could help answer how slow or fast osmolality is regulated for this species under changing salinity conditions. Further research in this direction is desirable, particularly given the daily movements of fish between water depths with different salinities. Ponwith and Neill (1995) hypothesized that changes in ambient salinity and impacts on the osmolality of adult body fluid were responsible for significant differences in the egg buoyancy in red drum (Sciaenops ocellatus L.). That study collected eggs from a broodstock adapted to a salinity of 28 and 32 for the first and second trials respectively. They suggested that "even if osmoregulation is marked in fish, euryhaline species may conform to their environment to 
a certain extent before the cost of active osmoregulation is warranted."

\section{Consequences of different salinities for yolk sac larvae}

Salinity during egg phase had a significant effect on YSA at hatching, with lower values at higher incubation salinities, but the duration of the yolk sac phase was not affected. This implies that suboptimal salinities did not lead to an earlier depletion of endogenous resources, at least in combination with the temperature conditions larvae experience in the field. However, the size of the yolk sac also regulates larval buoyancy. Within the first days post hatch, yolk sac larvae and eggs remain in the same water layers, but with continued development, neutral buoyancy of the former will not be obtained at the same depth. Increased salinity reduces passive sinking speed in larval Baltic cod (Rohlf, 1999). Whether higher salinity conditions are energetically favorable for sprat larvae (i.e. to counteract their sinking speed) was not analyzed in this study but would be an interesting topic for future research. Unlike the YSA, mean BA in all trials was not significantly different between salinities, but varied considerably at EP and YSD in all experimental salinities. This might be explained by phenotypic plasticity in the offspring originating from several females.

\section{Conclusion and outlook}

We have demonstrated that fertilization/incubation salinity can influence egg buoyancy patterns in Baltic sprat. An egg fertilization/incubation salinity difference of $\sim 12$ ( 8 to 20 or 18 to 30 ) resulted in a $\sim 0.002$ to $0.003 \mathrm{~g}^{*} \mathrm{~cm}^{-3}$ change in egg density. Seasonal differences in egg buoyancy could not be solely explained by fertilization salinity. Ovarian predetermination of egg density and/or changes in adult vertical distribution during oocyte maturation might be important factors. Understanding the factors that contribute to differences in egg buoyancy is especially important since changes in vertical position can strongly impact transport patterns of fish ELS. This may result in spatio-temporal differences of transport from spawning grounds to areas with a suitable or unsuitable habitat for eggs as well as for larval and juvenile fish. This is particularly the case in the Baltic Sea where there are strong vertical and horizontal (east-west) salinity gradients.
Egg buoyancy thresholds may be exceeded if winddriven advection transports eggs eastward into low salinity regions where eggs would sink and die due to low oxygen conditions at depth. The quantification of eastward-oriented drift of eggs and larval fish and the corresponding contribution of juveniles to eastern Baltic fish stocks may be helpful for management particularly during periods when the ratio between the spawning stock biomass of western and eastern stocks is relatively high compared to long term means.

\section{ACKNOWLEDGEMENTS}

This study was funded by the DFG grant RECONN2 (CL 126/3-2) within the priority program 1162 "AQUASHIFT" and with financial support from the European Commission (Contract No. 022717, "Understanding the mechanisms of stock recovery", UNCOVER). This study does not necessarily reflect its views and in no ways anticipates the Commission's future policy in this area. We gratefully acknowledge, Holger Haslob, Matthias Schaber and the crew of RV "ALKOR" for providing us with sprat eggs and Andrea Frommel, Anja Oelschlägel and Helena Hauss for assistance during the experimental density measurements. We also thank Dietrich Schnack for helpful comments and suggestions on earlier drafts of this manuscript.

\section{REFERENCES}

Alderdice, D.F. - 1988. Osmotic and Ionic Regulation in Teleost Eggs and Larvae. In: W.S. Hoar and D.J. Randall (eds.), Fish Physiology XI - The Physiology of Developing Fish - Part A Eggs and Larvae, pp. 163-252. Academic Press, London.

Alekseev, F.E. and E.I. Alekseeva. - 2005. Batch fecundity and daily egg production of the Baltic sprat (Sprattus sprattus balticus (Clupeidae)) from the southeastern part of the Baltic Sea. J. Ichthyol., 45(1): 93-102.

Aro, E. - 1989. A review of fish migration patterns in the Baltic Sea. Rapp. P.-v. Réun. Cons. Int. Explor. Mer, 190: 72-96.

BALTEX. - 2006. Assessment of Climate Change for the Baltic Sea basin. Summary. The BACC Lead Author Group (eds.), International BALTEX Secretariat, 35: 1-26.

Coombs, S.H. - 1981. A density-gradient column for determining the specific gravity of fish eggs, with particular reference to eggs from the mackerel Scomber scombrus. Mar. Biol., 63: 101-106.

Coombs, S.H., C.A. Fosh and M.A. Keen. - 1985. The buoyancy and vertical distribution of eggs of sprat (Sprattus sprattus) and pilchard (Sardina pilchardus). J. Mar. Biol. Assoc. UK, 65: 461-474.

Craik, J.C.A. and S.M. Harvey. - 1987. The causes of buoyancy in eggs of marine teleosts. J. Mar. Biol. Assoc. UK, 67: 169-182.

Fabra, M., D. Raldúa, D.M. Power, P.M. Deen and J. Cerdà - 2005. Marine fish egg hydration is aquaporine-mediated. Science, 307: 545. 
Fofonoff, P. and R.C. Millard Jr. - 1983. Algorithms for computation of fundamental properties of seawater. UNESCO Tech. Pap. Mar. Sci., 44: 53 pp.

Goarant, A., P. Petitgas and P. Bourriau - 2007. Anchovy (Engraulis encrasicolus) egg density measurements in the Bay of Biscay: evidence for the spatial variation in egg density with sea surface salinity. Mar. Biol., 151(5): 1907-1915.

Govoni, J.J. and R.B. Forward Jr. - 2008. Buoyancy. In: R.N. Finn and B.G. Kapoor (eds.), Fish Larval Physiology, pp. 495-521. Science Publishers, Enfield USA.

Grauman, G.B. and E. Yula. - 1989. The importance of abiotic and biotic factors in early ontogenesis of cod and sprat. Rapp. P.-v. Réun. Cons. Int. Explor. Mer, 190: 207-210.

Harjes, A. - 2008. Saisonaler Einfluss abiotischer und biotischer Faktoren auf den Überlebenserfolg von Fischbrut im Bornholmbecken. Staatsexamen thesis, Univ. Kiel.

Haslob, H., C. Clemmesen, M. Schaber, H.-H. Hinrichsen, J.O. Schmidt, R. Voss, G. Kraus and F.W. Köster. - 2007. Invading Mnemiopsis leidyi as a potential threat to Baltic fish. Mar. Ecol. Prog. Ser., 349: 303-306.

Hempel, G. - 1979. Early life history of marine fish. The Egg Stage, pp 1-70. University of Washington Press, Seattle Washington.

Hohendorf, K. - 1968. Zur Schwebfähigkeit pelagischer Fischeier in der Ostsee-vorläufige Mitteilung. Ber. Dt. Wiss. Komm. Meeresforsch., 3: 181-193.

Holliday, F.G.T. and J.H.S. Blaxter - 1960. The effect of salinity on the developing eggs and larvae of the herring. J. Mar. Biol. Assoc. UK, 39: 591-603.

Jacobsen, J.P. and A.C. Johansen - 1908. Remarks on the changes in specific gravity of pelagic fish eggs and the transportation of same in Danish waters. Medd. Kom. Dan. Fisk Havunders. Fisk, 3(2): 1-24.

Kamler, E. - 2002. Ontogeny of yolk-feeding fish: an ecological perspective. Rev. Fish. Biol. Fish., 12: 79-103.

Kändler, R. - 1941. Die Fortplanzung der Meeresfische in der Ostsee und ihre Beziehungen zum Fischereiertrag. Monatshefte $f$. Fischerei, 11: 158-163.

Kändler, R. and E.O. Tan - 1965. Investigation on the osmoregulation in pelagic eggs of gadoid and flatfishes in the Baltic. Part 1: Changes in volume and specific gravity at different salinities. Int. Counc. Explor. Sea Comm. Meet. (Baltic-Belt Sea), 43: 1-5.

Köster, F.W., H.-H. Hinrichsen, D. Schnack, M. St. John, B. MacKenzie, J. Tomkiewicz, C. Möllmann, G. Kraus, M. Plikshs, A. Makarchouk and E. Aro. - 2003. Recruitment of Baltic cod and sprat stocks: identification of critical life stages and incorporation of environmental variability into stock-recruitment relationships. Sci. Mar., 67(Suppl. 1): 129-154.

Köster, F.W. and C. Möllmann. - 2000. Egg cannibalism in Baltic sprat (Sprattus sprattus L.). Mar. Ecol. Prog. Ser., 196: 269-277.

Laurence, G.C. and W.H. Howell. - 1981. Embryology and influence of temperature and salinity on early development and survival of yellowtail flounder Limanda ferruginea. Mar. Ecol. Prog. Ser., 6: 11-18.

Muus, B.J. and J.G. Nielsen. - 1999. Die Meeresfische Europas in Nordsee, Ostsee und Atlantik. Franchk-Kosmos Verlags-GmbH and Co., Stuttgart.

Nissling, A. - 2004. Effects of temperature on egg and larval survival of cod (Gadus morhua) and sprat (Sprattus sprattus) in the Baltic Sea - implications for stock development. Hydrobiologia, 514: $115-123$.

Nissling, A., A. Müller and H.-H. Hinrichsen. - 2003. Specific gravity and vertical distribution of sprat eggs in the Baltic Sea. $J$. Fish Biol., 63: 280-299.

Nissling, A. and L. Westin. - 1997. Salinity requirements for successful spawning of Baltic and Belt Sea cod and the potential for cod stock interactions in the Baltic Sea. Mar. Ecol. Prog. Ser., 152: 261-271.

Nissling, A. and L. Vallin. - 1996. The ability of Baltic cod eggs to maintain neutral buoyancy and the opportunity for survival in fluctuating conditions in the Baltic Sea. J. Fish Biol., 48: 217-227.

Nissling, A., H. Kryvi and L. Vallin. - 1994a. Variation in egg buoyancy of Baltic cod (Gadus morhua) and its implications for egg survival in prevailing conditions in the Baltic Sea. Mar. Ecol. Prog. Ser., 110: 67-74.

Nissling, A., P. Solemdal, M. Svensson and L. Westin. - 1994b. Survival, activity and feeding ability of Baltic cod (Gadus morhua) yolk sac larvae at different salinities. J. Fish Biol., 45: 435-445.

Nissling, A. and L. Westin. - 1991a. Egg mortality and hatching rate of Baltic cod (Gadus morhua) in different salinities. Mar. Biol., 111: 29-32.

Nissling A. and L. Westin. - 1991b. Egg buoyancy of Baltic cod (Gadus morhua) and its implications for cod stock fluctuations in the Baltic. Mar. Biol., 111: 33-35.

Parmanne, R., O. Rechlin and B. Sjöstrand. - 1994. Status and future of herring and sprat stocks in the Baltic Sea. Dana, 10: 29-59.

Petereit, C., H. Haslob, G. Kraus and C. Clemmesen. - 2008. The influence of temperature on the development of Baltic Sea sprat (Sprattus sprattus) eggs and yolk sac larvae. Mar. Biol., 154: 295-306.

Ponwith, B.J. and W.H. Neill. - 1995. The influence of incubation salinity on the buoyancy of red drum eggs and yolk sac larvae. J. Fish Biol., 46: 955-960.

Rohlf, N. - 1999. Verhaltensänderungen der Larven des Ostseedorsches (Gadus morhua callarias) während der Dottersackphase. Ber. Inst. Meereskd. Christian-Albrechts-Univ. Kiel, 312: 1-52.

Sjöblom, V. and R. Parmanne. - 1980. Sprat off the coast of Finland in 1977 and 1978. Ann. Biol., 35: 200-203.

Stepputtis, D. - 2006. Distribution patterns of Baltic sprat (Sprattus sprattus L.) - causes and consequences. Ph.D thesis, Univ. Kiel.

Thompson B.M., S.P. Milligan and J.H. Nichols. - 1981. The development rates of Sprat (Sprattus sprattus L.) eggs over a range of temperatures. ICES CM 1981/H:15.

Thorsen, A., O.S. Kjesbu, H.J. Fyhn and P. Solemdal. - 1996. Physiological mechanisms of buoyancy in eggs from brackish water cod. J. Fish Biol., 48: 457-477.

Received October 17, 2008. Accepted July 10, 2009.

Published online October 5, 2009. 